\title{
Coverage and adequacy of ferrous sulfate supplementation in the prevention of anemia among children treated at health centers of Florianopolis, Santa Catarina
}

Cobertura e adequação da suplementação com sulfato ferroso na prevenção de anemia em crianças atendidas em centros de saúde de Florianópolis, Santa Catarina

Cobertura y adecuación de la suplementación con sulfato ferroso en la prevención de anemia entre niños atendidos en centros de salud informatizados de Florianópolis, Santa Catarina (Brasil)

Francieli Cembranel'1, Arlete Catarina T. Corso², David Alejandro González-Chica ${ }^{3}$

\section{ABSTRACT}

Objective: To evaluate the National Program of Iron Supplementation (PNSF) coverage, the compliance with the directions for of using of this supplementation and the association with sociodemographic factors in children aged six to 18 months old and registered in 35 public health centers of Florinópolis (Southern Brazil).

Methods: Cross-sectional study using secondary data obtained from the health information system of the Health Department of Florianópolis, Santa Catarina, Brazil (Infosaúde). Data on ferrous sulfate supplementation and sociodemographic variables were obtained of all children registered in PNSF in Florianópolis in 2010. STATA 11.0 software was used in the analyses.

Results: The PNSF covered 6.3\% (95\%CI 5.9-6.7) of the children; the compliance with the directions regarding age at the onset of supplementation and its frequency was adequate only in $2.4 \%$ of the cases $(95 \% \mathrm{CI} 1.5-3.7)$. There was no association with the child's gender, maternal education level and ethnicity or the distance from home to the health center.

Conclusions: This study showed low coverage and inadequate compliance with the PNSF directions. Measures to improve this strategy are urgent.

Key-words: anemia; iron deficiency; child; health policy; national health programs; health evaluation.

Instituição: Programa de Pós-Graduação em Nutrição da Universidade Federal de Santa Catarina (UFSC), Florianópolis, SC, Brasil

${ }^{1}$ Mestre pelo Programa de Pós-Graduação em Nutrição do Departamento de Nutrição da UFSC, Florianópolis, SC, Brasil

2Doutor em Saúde Pública pela Universidade de São Paulo (USP); ProfessorTitular do Programa de Pós-Graduação em Nutrição do Departamento de Nutrição da UFSC, Florianópolis, SC, Brasil

${ }^{3}$ Doutor em Epidemiologia pela Universidade Federal de Pelotas (UFPel); Professor-Adjunto do Programa de Pós-Graduação em Nutrição do Departamento de Nutrição da UFSC, Florianópolis, SC, Brasil

\section{RESUMO}

Objetivo: Avaliar a cobertura do Programa Nacional de Suplementação de Ferro (PNSF), o cumprimento da normativa de utilização da suplementação e a associação com fatores sociodemográficos em crianças de seis a 18 meses de idade, atendidas em 35 centros de saúde de Florianópolis, Santa Catarina.

Métodos: Estudo transversal com dados secundários obtidos do sistema de informações em saúde da Secretaria Municipal de Saúde de Florianópolis (Infosaúde). Obtiveram-se informações sociodemográficas e sobre a suplementação com sulfato ferroso de todas as crianças cadastradas no PNSF em Florianópolis em 2010. Utilizou-se o software STATA 11.0 nas análises.

Resultados: A cobertura do PNSF em crianças foi igual a 6,3\% (IC95\% 5,9-6,7), entre as quais a normativa da idade de início e a periodicidade da suplementação foi cumprida apenas em 2,4\% (IC95\% 1,5-3,7) dos casos. Não houve associação com o sexo da criança, a escolaridade e a cor da pele materna, nem com a distância do domicílio ao centro de saúde.

Conclusões: $\mathrm{O}$ estudo mostrou cobertura baixa e inadequação no cumprimento das normativas do PNSF, sendo urgente a adoção de medidas que melhorem essa estratégia.

Palavras-chave: anemia; deficiência de ferro; criança; política de saúde; programas nacionais de saúde; avaliação em saúde.

\author{
Endereço para correspondência: \\ David Alejandro González-Chica \\ Centro de Ciências da Saúde, $3^{\circ}$ andar - Campus Universitário \\ CEP 88040-900 - Florianópolis/SC \\ E-mail: david.epidemio@gmail.com
}

Conflito de interesse: nada a declarar

Recebido em: 8/3/2013

Aprovado em: 29/4/2013 


\section{RESUMEN}

Objetivo: Evaluar la cobertura del Programa Nacional de Suplementación de Ferro (PNSF), el cumplimiento de la normativa de utilización de la suplementación y la asociación con factores sociodemográficos en niños de 6 a 18 meses atendidos en 35 centros de salud informatizados de Florianópolis, Santa Catarina (Brasil).

Métodos: Estudio transversal con datos secundarios obtenidos del sistema de informaciones en salud de la Secretaría Municipal de Salud de Florianópolis (Infosaúde). Se obtuvieron informaciones sociodemográficas y sobre la suplementación con sulfato ferroso de todos los niños registrados en el PNSF en Florianópolis, en 2010. Se utilizó el software STATA 11.0 en los análisis.

Resultados: La cobertura del PNSF en niños fue igual a 6,3\% (IC95\% 5,9-6,7), entre los que la normativa de la edad de inicio y la periodicidad de la suplementación se cumplió en solamente un 2,4\% (IC95\% 1,5-3,7) de los casos. No hubo asociación con el sexo del niño, la escolaridad y el color de la piel materna, tampoco con la distancia del domicilio al centro de salud.

Conclusiones: El estudio mostró cobertura baja e inadecuación en el cumplimiento de las normativas del PNSF, siendo urgente la adopción de medidas que mejoren esa estrategia.

Palabras clave: anemia; deficiencia de hierro; niño; política de salud; programas nacionales de salud; evaluación en salud.

\section{Introduction}

Anemia is defined by the World Health Organization (WHO) as a pathological process in which hemoglobin concentration in blood is abnormally low, as a result of the deficiency of one or more essential nutrients. Its main cause comes from iron deficiency, characterizing thus the so-called iron-deficiency anemia ${ }^{(1)}$.

According to WHO estimates, iron-deficiency anemia affects nearly $47.4 \%$ of preschool children worldwide ${ }^{(2)}$. In Brazil, this disease represents a major public health problem, affecting one in every two children below five years of age $(54.9 \%)^{(2)}$. Studies conducted in several regions of the country showed high prevalence rates of anemia, especially among children below two years of age $e^{(3-7)}$. In this age group, anemia is associated with several negative health consequences, including weakness of the immune system and impairments in cognitive and motor development ${ }^{(8)}$.
Among the strategies recommended for its prevention, one of the most important is prophylactic iron supplementation $^{(9)}$, which, in Brazil, originated the National Program of Iron Supplementation (Programa Nacional de Suplementação de Ferro-PNSF). This program establishes that every children from six to 18 months old should receive supplementation with $25 \mathrm{mg}$ of elemental iron once a week in the form of ferrous sulfate syrup ${ }^{(10)}$. Therefore, the PNSF appears as a strategy with potential for contributing to the improvement in iron status in the first years of life.

However, in order for the program to reach its desired goals, it is necessary to know first whether its actions are effectively implemented according to the established standards. The evaluations of the different indicators of effectiveness (offer, use, coverage and/or impact) of this type of program are essential and serve as the basis for political decision making, planning, and reordering of priorities ${ }^{(11)}$. Thus, despite the unquestionable importance of assessing the different indicators of health and nutrition programs, few studies located in the literature that evaluated these indicators in relation to the $\mathrm{PNSF}^{(12,13)}$. So, this study aimed to evaluate PNSF coverage in children from six to 18 months old treated at 35 public health centers in Florianópolis, state of Santa Catarina, Brazil, in 2010, as well as the compliance with the normative regarding the use of iron supplementation in children registered in the program, establishing its relationship with sociodemographic factors.

\section{Method}

This study was carried out in the city of Florianópolis, southern Brazil. According to a population census conducted by the Brazilian Institute of Geography and Statistics in 2010, this city has a population of nearly 421,240 inhabitants ${ }^{(14)}$. In that year, the public health network of Florianópolis had 49 health centers (HC) to treat the population, distributed into five health districts (downtown, continent, east, north, and south $)^{(15)}$. The design chosen was that of the crosssectional type, using as source of information a secondary database, the Infosaúde system (version 3.4.5.45). This system was created in 2002 by the Department of Informatics of the Municipal Health Department of Florianópolis and stores individual medical charts from all patients treated at the computerized HCs of the city. In the beginning of 2010, of the total of HCs in Florianópolis ( $\mathrm{n}=49$ ), 35 were already computerized with Infosaúde ${ }^{(16)}$. Information for this research was obtained from the 35 computerized HCs 
and located at the five health districts of the city: downtown (5/6), continent (9/11), east (4/9), north (6/11), and south (11/13). The population treated at the 35 HCs corresponds to $80 \%$ of all people living in the city ${ }^{(17)}$, and the distribution by gender and age group of this population is similar to that of people living in areas not covered by Infosaúde.

All children registered in the PNSF in Florianópolis in 2010 were included. In order to obtain the information of interest, the electronic medical charts of all children registered in the program were reviewed between July and October 2011. Medical charts were accessed directly at the Department of Informatics of the Municipal Health Secretariat of Florianópolis.

Two indicators were considered as dependent variables of the study. The first one was PNSF coverage, obtained by dividing the total number of children registered in the PNSF in 2010 by the total number of children aged from six to 18 months treated and registered in the 35 computerized HCs in that year.

The second evaluated indicator was compliance with the iron supplementation normative. This indicator was determined considering the age when children received the first dose of ferrous sulfate and the frequency in which they received the remaining supplement bottles. According to the PNSF, all children from six to 18 months old should receive a bottle of $60 \mathrm{~mL}$ of ferrous sulfate syrup every three months in order to comply with the recommended dose of $5 \mathrm{~mL}$ once a week ( $25 \mathrm{mg}$ of elemental iron) ${ }^{(10)}$. Thus, the variable "compliance with normative" was established in three categories:

Adequate: onset of supplementation until six months of age (+15 days) and obtainment of a supplement bottle every three months ( +15 days). In order to be classified in this category, a margin of error of +15 days was added, both for children's age at the onset of supplementation and for the frequency in which they received the remaining bottles of ferrous sulfate, due to possible delays in scheduling consultations at the HC.

Inadequate: onset of supplementation after nine months of age and/or obtainment of a supplement bottle every six months or more. The time intervals for both conditions were determined considering that they allowed for the onset of anemia, either because breast milk did not achieve meet child's needs or because the time without supplementation would be extensive enough to allow for the onset of the disease ${ }^{(18,19)}$.

Intermediate: children in the remaining situations, i.e., onset of supplementation after 6.5 months and up to nine months of age and obtainment of the supplement at intervals higher than 3.5 months and lower than six months.
In order to determine this variable, children's age at the onset of supplementation was estimated through the difference between the date they received the first bottle of ferrous sulfate and the date they were born. In turn, the adequacy of the frequency of receipt of the remaining bottles of ferrous sulfate was established based on the dates of obtainment of each supplement bottle (recorded in the child's medical chart) and on the number of bottles received. From this information, average time between obtainments was estimated for each child.

The independent variables analyzed were: child's gender (female or male); maternal skin color (White or Others); maternal education level in years of study (zero to eight; nine to $11 ; 12$ or more years of study); geographical area of the HC (downtown, continent, east, north and south); and distance from child's home to the HC. This variable was measured using the Google maps mapping system ${ }^{(20)}$, based on child's home address and on the address of the HC in which the child was registered in the PNSF. When the child's address was not found on Google maps, an additional tool was used (Busca CEP) ${ }^{(21)}$, estimating the distance from the nearest zip code. The distance from home to $\mathrm{HC}$ was grouped into three categories: $<1 \mathrm{~km}, 1-3 \mathrm{~km}$, and $>3 \mathrm{~km}$.

Data corresponding to dependent and independent variables were inserted into a Microsoft Office Excel 2007 spreadsheet (Microsoft Corp., United States) and checked twice in order to identify possible typing errors. After this verification, all the information was codified. The STATA 11.0 software (Stata Corp., College Station, United States) was used for statistical analysis. The number of HCs included and the population covered by them were considered for estimating sample weights, and the set of commands "survey" (svy) from STATA was used in all analyses. In descriptive analyses, data were expressed as prevalence and its $95 \%$ confidence interval $(95 \% \mathrm{CI})$, and the chi-square test was applied to verify possible associations between variables, in the case of bivariate analyses. Values were considered statistically significant if $p<0.05$.

The project was formally authorized by the Health Department of Florianópolis and approved by the Research Ethics Committee of Universidade Federal de Santa Catarina project no. 2042/2011 - in compliance with Resolution 196/96 of the Brazilian National Health Council ${ }^{(22)}$.

\section{Results}

During the year 2010, 13,197 children aged between six and 18 months old were registered in the $35 \mathrm{HCs}$ computerized with 
Infosaúde. Of these children, 834 were registered in the $\mathrm{PNSF}^{(16)}$, which corresponds to a coverage of $6.3 \%$ (95\%CI 5.9-6.7).

Table 1 shows that, among children registered in the PNSF, slightly more than a half was male. As for maternal characteristics, almost $80 \%$ of mothers were classified as Caucasian and less than $10 \%$ had 12 or more years of education. As for $\mathrm{HC}$ geographical area, south and downtown health districts of the island showed the higher number of children registered in HCs. In terms of distance from home to $\mathrm{HC}$, slightly more than a third of children lived less than $1 \mathrm{~km}$ away from the $\mathrm{HC}$, while $22.2 \%$ of them lived more than $3 \mathrm{~km}$ away from it.

When child's age at the onset of supplementation was evaluated (Table 1), it was found that less than a half of children began supplementation with up to six months of age (+15 days), while almost one third of them began it when they were more than nine months old. As for continuation of supplementation, more than $80 \%$ of children received bottles of ferrous sulfate at intervals higher than six months, while only $7.3 \%$ of children received supplementation at the time intervals established by the PNSF.

Only $2.4 \%$ (95\% CI 1.5-3.7) of children registered in the PNSF showed adequate compliance with the program guidelines regarding child's age at the onset of supplementation and frequency of obtainment of ferrous sulfate bottles (Graph 1). Compliance with normatives was inadequate in $90.2 \%$ of children (95\% CI 87.9-92.1), and intermediate in $7.5 \%$ of the cases (95\% CI 5.8-9.4). In the case of inadequate compliance with normatives, the problem was age at the onset of supplementation ( $>9$ months) in $8.4 \%$ of children, inadequate frequency of obtainment of ferrous sulfate bottles (intervals higher than six months) in $62.3 \%$, and both conditions in $19.5 \%$.

When analyzing the association of socioeconomic and demographic variables with compliance with normatives

Table 1 - Characteristics of the children registered in the National Program of Iron Supplementation according to sociodemographic variables, in Florianópolis, state of Santa Catarina, Brazil, 2010

\begin{tabular}{|c|c|c|c|}
\hline Variables & $\mathbf{n}$ & $\%$ & $95 \% \mathrm{Cl}$ \\
\hline \multicolumn{4}{|l|}{ Gender } \\
\hline Female & 389 & 46.7 & $43.2-50.1$ \\
\hline Male & 445 & 53.3 & $49.9-56.8$ \\
\hline \multicolumn{4}{|l|}{ Maternal skin color } \\
\hline White & 609 & 79.8 & $76.8-82.6$ \\
\hline Other & 154 & 20.2 & $17.4-23.2$ \\
\hline \multicolumn{4}{|l|}{ Maternal education level (years) } \\
\hline $0-8$ & 375 & 49.1 & $45.4-52.6$ \\
\hline $9-11$ & 329 & 43.2 & $39.6-46.7$ \\
\hline$\geq 12$ & 59 & 7.8 & $5.9-9.9$ \\
\hline \multicolumn{4}{|c|}{ Geographical area of the health center } \\
\hline Downtown & 212 & 25.5 & $22.6-28.6$ \\
\hline Continent & 126 & 15.1 & $12.7-17.7$ \\
\hline East & 46 & 5.5 & $4.1-7.3$ \\
\hline North & 189 & 22.7 & 19.9-25.7 \\
\hline South & 261 & 31.3 & $28.2-34.6$ \\
\hline \multicolumn{4}{|c|}{ Distance from home to health center $(\mathrm{km})$} \\
\hline$<1$ & 310 & 37.2 & $33.9-40.6$ \\
\hline $1-3$ & 339 & 40.6 & $37.3-44.1$ \\
\hline$>3$ & 185 & 22.2 & $19.4-25.2$ \\
\hline \multicolumn{4}{|c|}{ Age at the onset of supplementation (months) } \\
\hline$\leq 6.5$ (adequate) & 363 & 43.6 & $40.1-47.0$ \\
\hline$>6.5-9$ (intermediate) & 238 & 28.5 & $25.5-31.7$ \\
\hline$>9$ (inadequate) & 233 & 27.9 & 24.9-31.1 \\
\hline \multicolumn{4}{|c|}{ Frequency of obtainment of ferrous sulfate bottles (months) } \\
\hline$\leq 3.5$ (adequate) & 61 & 7.3 & $5.6-9.3$ \\
\hline$>3.5$ and $<6$ (intermediate) & 92 & 11.0 & $9.0-13.4$ \\
\hline$\geq 6$ (inadequate) & 681 & 81.7 & $79.0-84.3$ \\
\hline
\end{tabular}


regarding the use of iron supplementation, a statistically significant association was obtained only with HC geographical area. In continent and east health districts, no children showed adequate compliance with the normatives, and a low percentage of adequacy was observed in downtown, north and south districts. The percentage of inadequacy ranged between 85 and $93 \%(p<0.001)$ (Table 2).

On the other hand, when evaluating the association of the same variables with adequacy of child's age at the onset of supplementation, there was a higher percentage

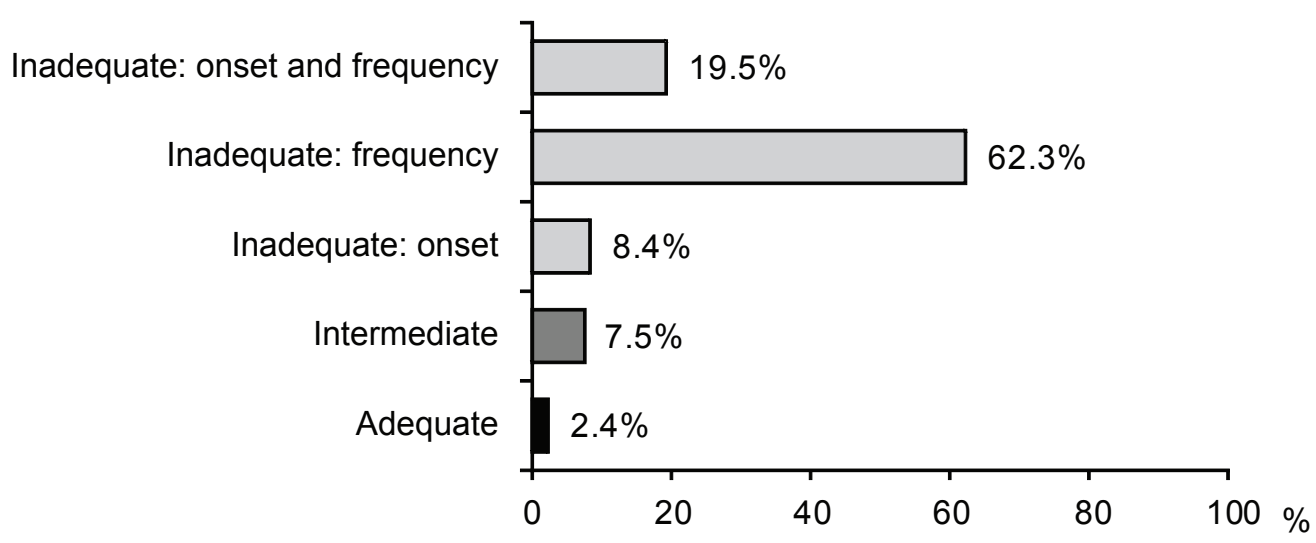

Graph 1 - Compliance with normatives regarding supplementation use from the National Program of Iron Supplementation in Florianópolis, state of Santa Catarina, Brazil, 2010, according to the child's age at the onset of supplementation and frequency of obtainment of ferrous sulfate bottles

Table 2 - Association between sociodemographic variables and compliance with normatives regarding supplementation use among children registered in the National Program of Iron Supplementation in Florianópolis, state of Santa Catarina, Brazil, 2010

\begin{tabular}{|c|c|c|c|c|c|c|c|c|}
\hline \multirow{3}{*}{ Variables } & \multirow{3}{*}{$\mathbf{n}$} & \multicolumn{6}{|c|}{$\begin{array}{c}\text { Compliance with PNSF normatives regarding } \\
\text { supplementation use }\end{array}$} & \multirow{3}{*}{$p$-value } \\
\hline & & \multicolumn{2}{|c|}{ Adequate } & \multicolumn{2}{|c|}{ Intermediate } & \multicolumn{2}{|c|}{ Inadequate } & \\
\hline & & $\%$ & $95 \% \mathrm{Cl}$ & $\%$ & $95 \% \mathrm{Cl}$ & $\%$ & $95 \% \mathrm{Cl}$ & \\
\hline \multicolumn{9}{|l|}{ Gender } \\
\hline Female & 389 & 2.2 & $1.3-3.4$ & 9.9 & $7.9-12.1$ & 88.0 & $85.6-90.1$ & \multirow{2}{*}{0.051} \\
\hline Male & 445 & 2.6 & $1.6-3.8$ & 5.3 & $4.0-7.2$ & 92.1 & $90.0-93.8$ & \\
\hline \multicolumn{9}{|c|}{ Maternal skin color } \\
\hline White & 609 & 2.1 & $1.2-3.4$ & 7.2 & $5.5-9.3$ & 90.7 & 88.4-92.7 & \multirow[t]{2}{*}{0.651} \\
\hline Other & 154 & 2.5 & $1.5-3.9$ & 9.3 & $7.3-11.6$ & 88.2 & $85.7-90.4$ & \\
\hline \multicolumn{9}{|c|}{ Maternal education level (years) } \\
\hline $0-8$ & 375 & 3.2 & $2.0-4.6$ & 8.1 & $6.3-10.3$ & 88.7 & $86.3-90.9$ & \multirow{3}{*}{0.435} \\
\hline $9-11$ & 329 & 1.2 & $0.5-2.2$ & 6.8 & $5.1-8.8$ & 92.0 & $89.8-93.8$ & \\
\hline$\geq 12$ & 59 & 1.6 & $0.8-2.7$ & 9.0 & $7.1-11.3$ & 89.4 & $87.0-91.5$ & \\
\hline \multicolumn{8}{|c|}{ Geographical area of the health center } & \multirow{6}{*}{0.001} \\
\hline Downtown & 212 & 1.6 & $0.8-2.7$ & 8.0 & $6.2-10.0$ & 90.4 & $88.2-92.3$ & \\
\hline Continent & 126 & 0 & - & 7.0 & $5.4-9.0$ & 93.0 & $91.0-94.6$ & \\
\hline East & 46 & 0 & - & 10.3 & $8.3-12.6$ & 89.7 & 87.4-91.7 & \\
\hline North & 189 & 5.1 & $3.8-6.9$ & 9.6 & $7.7-11.8$ & 85.3 & $82.7-87.6$ & \\
\hline South & 261 & 2.6 & $1.7-4.0$ & 5.2 & $3.8-6.9$ & 92.2 & $90.2-93.9$ & \\
\hline \multicolumn{9}{|c|}{ Distance from home to health center $(\mathrm{km})$} \\
\hline$<1$ & 310 & 2.1 & $1.3-3.4$ & 6.9 & $5.3-8.9$ & 90.9 & $88.7-92.8$ & \multirow{3}{*}{0.962} \\
\hline $1-3$ & 339 & 2.3 & $1.4-3.5$ & 7.7 & $6.0-9.7$ & 90.1 & $87.8-92.0$ & \\
\hline$>3$ & 185 & 3.0 & $2.0-4.4$ & 7.9 & $6.2-10.0$ & 89.1 & $86.8-91.1$ & \\
\hline
\end{tabular}


of inadequacy in children registered in the HCs from the east health district, while adequacy was higher in north and south districts. None of the other variables investigated were associated with this outcome (Table 3).

Similarly, when evaluating the association of exposure variables with adequacy of frequency of supplement obtainment (Table 4), only HC geographical area was associated with this outcome, with higher percentages of adequacy in HCs from the north health district $(p=0.001)$.

\section{Discussion}

This is the first study found in the scientific literature that evaluated the PNSF in a municipality of the state of Santa Catarina, Brazil. The implementation of the PNSF in Florianópolis took place in $2008^{(23)}$, and the data collected in this study showed that program coverage is very low in this city, including only $6.3 \%$ of all children from six and 18 months old. This result was below that expected by the Brazilian Ministry of Health, which predicted an expected coverage of at least $60 \%$ for the year 2010 in cities with more than one hundred thousand inhabitants ${ }^{(10)}$.

Data reported on the website of the General Coordination of Food and Nutrition (Coordenação Geral de Alimentação e Nutrição, CGAN) show that Brazil as a whole experienced a gradual increase in PNSF coverage ${ }^{(24)}$. In 2006, one year after the implementation of the program, national coverage among children was $19.4 \%$ (only 11 of the 27 states showed results higher than this value); in Santa Catarina, it reached $2.4 \%$. In turn, in 2010 , national coverage rose to $27.2 \%$ (16 states with results above the national average), and Santa Catarina (6.7\%), São Paulo (9.5\%), and Amapá (3.2\%) were the only states to remain with coverage levels below $10 \%{ }^{(24)}$.

As part of a public policy that aims to provide universal access, the reduced number of children covered by the PNSF is a source of concern, considering the high prevalence of anemia in this age group in Brazil $(22.2-54.0 \%)^{(25)}$, even in regions with better socioeconomic development, such as south and southeast, reason why there would not be justification for the low coverage found in the present study.

Table 3 - Association between sociodemographic variables and adequacy of age at the onset of supplementation among children registered in the National Program of Iron Supplementation, in Florianópolis, state of Santa Catarina, Brazil, 2010

\begin{tabular}{|c|c|c|c|c|c|c|c|c|}
\hline \multirow{3}{*}{ Variables } & \multirow{3}{*}{$\mathbf{n}$} & \multicolumn{6}{|c|}{$\begin{array}{c}\text { Adequacy of child's age at the onset of ferrous sulfate } \\
\text { supplementation }\end{array}$} & \multirow{3}{*}{$p$-value } \\
\hline & & \multicolumn{2}{|c|}{ Adequate } & \multicolumn{2}{|c|}{ Intermediate } & \multicolumn{2}{|c|}{ Inadequate } & \\
\hline & & $\%$ & $95 \% \mathrm{Cl}$ & $\%$ & $95 \% \mathrm{Cl}$ & $\%$ & $95 \% \mathrm{Cl}$ & \\
\hline \multicolumn{9}{|l|}{ Gender } \\
\hline Female & 389 & 43.6 & $40.3-47.1$ & 29.9 & $26.8-33.1$ & 26.5 & $23.5-29.6$ & \multirow[t]{2}{*}{0.618} \\
\hline Male & 445 & 43.5 & $40.1-47.0$ & 27.3 & $24.3-30.5$ & 29.1 & $26.1-32.4$ & \\
\hline \multicolumn{9}{|c|}{ Maternal skin color } \\
\hline White & 609 & 44.5 & $41.0-48.2$ & 27.0 & $23.9-30.3$ & 28.5 & $25.3-31.8$ & \multirow[t]{2}{*}{0.817} \\
\hline Other & 154 & 42.0 & $38.4-45.5$ & 29.2 & $26.0-32.6$ & 28.9 & $25.6-32.2$ & \\
\hline \multicolumn{9}{|c|}{ Maternal education level (years) } \\
\hline $0-8$ & 375 & 44.2 & $40.6-47.8$ & 25.2 & $22.1-28.4$ & 30.6 & $27.4-34.1$ & \multirow{3}{*}{0.131} \\
\hline $9-11$ & 329 & 44.5 & $40.9-48.0$ & 27.6 & $24.5-31.0$ & 27.9 & $24.8-31.3$ & \\
\hline$\geq 12$ & 59 & 40.2 & $36.6-43.7$ & 40.8 & $37.3-44.3$ & 19.1 & $16.4-22.1$ & \\
\hline \multicolumn{8}{|c|}{ Geographical area of the health center } & \multirow{6}{*}{0.036} \\
\hline Downtown & 212 & 39.8 & $36.5-43.2$ & 28.7 & $25.6-31.9$ & 31.5 & $28.3-34.7$ & \\
\hline Continent & 126 & 37.5 & $34.2-40.9$ & 34.4 & $31.2-37.8$ & 28.1 & $25.2-31.4$ & \\
\hline East & 46 & 27.6 & $24.6-30.8$ & 31.0 & $27.9-34.3$ & 41.4 & $38.0-44.8$ & \\
\hline North & 189 & 49.4 & $46.0-52.9$ & 21.8 & $19.1-24.8$ & 28.9 & $25.8-32.1$ & \\
\hline South & 261 & 48.2 & $44.8-51.7$ & 30.0 & $26.9-33.2$ & 21.9 & $19.1-24.8$ & \\
\hline \multicolumn{8}{|c|}{ Distance from home to health center $(\mathrm{km})$} & \multirow{4}{*}{0.165} \\
\hline$<1$ & 310 & 38.4 & $35.1-41.8$ & 30.9 & $27.8-34.2$ & 30.7 & $27.6-34.0$ & \\
\hline $1-3$ & 339 & 44.8 & $41.3-48.2$ & 28.2 & $25.2-31.4$ & 27.1 & $24.1-30.3$ & \\
\hline$>3$ & 185 & 50.1 & $46.7-53.6$ & 25.2 & $22.3-28.3$ & 24.7 & $21.8-27.8$ & \\
\hline
\end{tabular}


Among the possible reasons for this low coverage, one of the most important is the reduced offer of supplements at the HCs. Data reported by the CGAN ${ }^{(24)}$ show that, in 2010 , a total of $15,816,579$ bottles of ferrous sulfate were distributed to the 5,556 Brazilian municipalities in order to treat cover $2,423,824$ children from six to 18 months old, who should be covered by the PNSF (average of 7.0 bottles/child; $\mathrm{SD}=4.1$ ). Observing the number of children really covered by the program in that year $(n=658,642)$, and considering that each of them had received the five bottles recommended by the PNSF, there would be an excess of more than 12.5 million bottles, which should be used to achieve the national program goals. However, despite this excess, slightly more than 140 thousand bottles were distributed in Santa Catarina to attend 87,201 children from six to 18 months old (average of 1.6 bottles/child). Thus, at the national level, supplement offer seems not to be a limiting factor for PNSF coverage, contrary to what data indicate for Santa Catarina.
The results for this research show also that difficulties are limited not only to PNSF coverage, but also to the compliance with the normative regarding the use of iron supplementation. Less than a half of the children covered by the program in Florianópolis began supplementation before 6.5 months of age (mean age of 7.7 months; $\mathrm{SD}=3.1$ ), and only $7.3 \%$ received a bottle of ferrous sulfate every three months. Although no other studies performed in Santa Catarina and in Brazil have been found to compare this result, the $\mathrm{WHO}^{(19)}$ highlights the importance of preventive supplementation after the sixth month of life, due to the increased need of iron experienced by children for their growth and development. Depending on breastfeeding practices, a depletion of organic iron reserves takes place between four and six months, and an inadequate supply of this mineral during this period make the child vulnerable to anemia ${ }^{(18,19)}$.

According to Schultink et al ${ }^{(26)}$ and Batista Filho and Ferreira ${ }^{(27)}$, the inefficiency of iron supplementation programs is caused, in many cases, by difficulties in operationalizing

Table 4 - Association between sociodemographic variables with the adequacy of frequency of obtainment of ferrous sulfate bottles among children registered in the National Program of Iron Supplementation, in Florianópolis, state of Santa Catarina, Brazil, 2010

\begin{tabular}{|c|c|c|c|c|c|c|c|c|}
\hline \multirow{3}{*}{ Variables } & \multirow{3}{*}{$\mathbf{n}$} & \multicolumn{6}{|c|}{$\begin{array}{l}\text { Adequacy of the frequency of obtainment } \\
\text { of ferrous sulfate bottles }\end{array}$} & \multirow{3}{*}{$p$-value } \\
\hline & & \multicolumn{2}{|c|}{ Adequate } & \multicolumn{2}{|c|}{ Intermediate } & \multicolumn{2}{|c|}{ Inadequate } & \\
\hline & & $\%$ & $95 \% \mathrm{Cl}$ & $\%$ & $95 \% \mathrm{Cl}$ & $\%$ & $95 \% \mathrm{Cl}$ & \\
\hline \multicolumn{9}{|l|}{ Gender } \\
\hline Female & 389 & 7.9 & $6.2-10.0$ & 12.8 & $10.6-15.3$ & 79.3 & 76.3-82.0 & 0.225 \\
\hline Male & 445 & 6.7 & $5.1-8.6$ & 9.4 & $7.5-11.5$ & 83.9 & $81.3-86.4$ & \\
\hline \multicolumn{9}{|c|}{ Maternal skin color } \\
\hline White & 609 & 7.1 & $5.4-9.1$ & 10.5 & $8.4-12.9$ & 82.5 & 79.6-85.1 & 0.329 \\
\hline Other & 154 & 8.3 & $6.5-10.6$ & 14.3 & $11.9-17.0$ & 77.3 & $74.2-80.3$ & \\
\hline \multicolumn{9}{|c|}{ Maternal education level (years) } \\
\hline $0-8$ & 375 & 8.8 & $6.9-11.0$ & 10.6 & $8.4-12.9$ & 80.6 & $77.6-83.4$ & 0612 \\
\hline $9-11$ & 329 & 6.1 & $4.5-8.0$ & 11.9 & $9.7-14.4$ & 82.0 & $79.1-84.7$ & 0.012 \\
\hline$\geq 12$ & 59 & 4.7 & $3.3-6.5$ & 12.1 & $9.8-14.6$ & 83.2 & $80.4-85.8$ & \\
\hline \multicolumn{9}{|c|}{ Geographic area of the health center } \\
\hline Downtown & 212 & 5.6 & $4.2-7.4$ & 12.8 & $10.5-15.2$ & 81.7 & 78.9-84.2 & \\
\hline Continent & 126 & 3.9 & $2.7-5.5$ & 10.2 & $8.2-12.5$ & 85.9 & $83.4-88.3$ & \\
\hline East & 46 & 3.5 & $2.3-5.0$ & 20.7 & 18.0-23.7 & 75.9 & $72.9-78.8$ & 0.001 \\
\hline North & 189 & 14.7 & $12.4-17.3$ & 12.2 & $10.1-14.7$ & 73.1 & $69.9-76.0$ & \\
\hline South & 261 & 5.6 & $4.1-7.3$ & 7.4 & $5.8-9.4$ & 87.0 & $84.6-89.3$ & \\
\hline \multicolumn{9}{|c|}{ Distance from home to health center $(\mathrm{km})$} \\
\hline$<1$ & 310 & 6.5 & $4.9-8.4$ & 10.9 & 8.9-13.2 & 82.6 & 79.9-85.1 & \\
\hline $1-3$ & 339 & 5.6 & $4.2-7.4$ & 10.7 & $8.7-13.0$ & 83.7 & $81.0-86.1$ & 0.133 \\
\hline$>3$ & 185 & 11.7 & $9.6-14.1$ & 11.7 & $9.6-14.1$ & 76.5 & $73.5-79.3$ & \\
\hline
\end{tabular}


this type of strategy — including those related to supplies, distribution and non-prescription of the supplement by health care professionals - as well as lack of adherence ${ }^{(13)}$. In the specific case of the PNSF, some measures have been taken since its conception in order to improve adherence and minimize the side effects of the supplement, including the development of a product with better sensory characteristics than those of other supplements traditionally used in the basic healthcare network ${ }^{(10)}$. Additionally, since 2011, alternative solutions to the conventional supplementation scheme, which are still in phase of study, have been suggested; for instance, offering iron along with other micronutrients (in a powdered version) as a possible strategy to reduce side effects and increase adherence to the program ${ }^{(28,29)}$.

Finally, it should be highlighted that the use of secondary data may be pointed out as a limitation of this study. However, as the findings regarding coverage were similar to those provided by the CGAN ${ }^{(24)}$, information from Infosaúde can be considered a reliable data source for conducting population-based investigations. Nonetheless, the use of secondary data did not allowed to evaluate other aspects related to low coverage or lack of compliance with PNSF normatives. Lastly, considering that $71 \%$ of the HCs were computerized in 2010 and that the population distribution by gender and age group was similar in areas covered and not covered by Infosaúde, the likelihood of selection bias in the results of this study can be considered low, and thus they may be extrapolated to the remaining children from six to 18 months old, although not all HCs of the city were evaluated.

\section{References}

1. World Health Organization. Nutritional anaemias: report of a WHO scientific group [Technical Report Series n 405]. Geneva: WHO; 1968.

2. World Health Organization. Centers for Disease Control and Prevention Atlanta. Worldwide prevalence of anaemia 1993-2005: WHO global database on anaemia. Geneva: WHO; 2008.

3. Monteiro CA, Szarfarc SC, Mondini L. Secular trends in child anemia in S. Paulo city, Brazil (1984-1996). Rev Saude Publica 2000;34 (Suppl 6):62-72.

4. Neuman NA, Tanaka OY, Szarfarc SC, Guimarães PR, Victora CG. Prevalence and risk factors for in Southern Brazil. Rev Saude Publica 2000;34:56-63.

5. Lima AC, Lira PI, Romani SA, Eickmann SH, Piscoya MD, Lima MC. Determinant factors of haemoglobin levels in 12 months old infants in the South of the Zona da Mata of Pernambuco. Rev Bras Saude Mater Infant 2004;4:35-43.

6. Brasil - Ministério da Saúde - Centro Brasileiro de Análise e Planejamento [homepage on the Internet]. PNDS 2006: dimensões do processo reprodutivo e da saúde da criança. Brasília: Ministério da Saúde; 2009 [cited 2013 May 24]. Available from: http://bvsms.saude.gov.br/bvs/publicacoes/pnds_crianca_ mulher.pdf
In conclusion, this study found not only a low PNSF coverage but also a low percentage of children complying with normatives regarding the onset and/or frequency of supplementation. The lack of association with distance from home to HC, maternal education level and maternal skin color suggests that neither the access to health care services nor socioeconomic conditions were factors that may have affected the correct implementation of this strategy in Florianópolis. Thereby, it can be concluded that difficulties would be related to problems in distribution and/or lack of prescription of the supplement by healthcare professionals, although new investigations are necessary to investigate these aspects. Thus, it is suggested that the PNSF needs to improve training and awareness strategies of healthcare professionals, involving Health Community Workers as essential elements for the adherence of families to the program.

\section{Acknowledgments}

The authors would like to thank the Municipal Health Secretariat of Florianópolis, Santa Catarina, especially to the Department of Informatics, which provided access to Infosaúde, and also the Post-Graduate Program in Nutrition at Universidade Federal de Santa Catarina (UFSC) - Program to Support the Restructuration and Expansion Plan of Federal Universities (Plano de Reestruturação e Expansão das Universidades Federais, REUNI)/Coordination of Improvement of Higher Education Personnel (Coordenação de Aperfeiçoamento de Pessoal de Nivel Superior, CAPES) for the master's scholarship that enabled the completion of this research.

7. Castro TG, Silva-Nunes M, Conde WL, Muniz PT, Cardoso MA. Anemia and iron deficiency among schoolchildren in the Western Brazilian Amazon: prevalence and associated factors. Cad Saude Publica 2011;27:131-42.

8. Lozoff B. Explanatory mechanisms for poorer developmental in iron-deficient anemic infants. In: Grantham-McGregor SM, editor. Nutrition, health and child development: research advances and policy recommendations. Washington: Pan American Health Organization; 1998. p. 162-78.

9. Shibukawa AF, Silva EM, Ichiki WA, Strufaldi MW, Puccini RF. Prophylaxis for iron deficiency anemia using ferrous sulfate among infants followed up at a primary healthcare unit in the municipality of Embu-SP (2003/2004). Sao Paulo Med J 2008;126:96-101.

10. Brasil - Ministério da Saúde [homepage on the Internet]. Portaria $n^{\circ} 730$, de 13 de maio de 2005. Institui o Programa Nacional de Suplementação de Ferro, destinado a prevenir a anemia ferropriva e dá outras providências. Brasília: Ministério da Saúde; 2005 [cited 2013 May 24]. Available from: http://dtr2001. saude.gov.br/sas/PORTARIAS/Port2005/GM/GM-730.htm

11. Santos IS. Evaluation of nutritional programs's impact. Rev Nutr 2009;22:141-50. 
12. Sousa CM, Mesquita LC, Souza SR, Alberto NS, Lima ME. Coverage of the program health of iron in the community of Teresina - PI, in the period of 2006-2008. Revista Interdisciplinar NOVAFAPI 2009;2:9-13.

13. Azeredo CM, Cotta RM, Silva LS, Franceschini SC, Sant'Ana LF, Ribeiro RC. Implementation and impact of the National Iron Supplementation Program in the city of Viçosa, State of Minas Gerais. Cien Saude Colet 2011;16:4011-22.

14. Brasil. Instituto Brasileiro de Geografia e Estatística [homepage on the Internet]. Censo 2010. Santa Catarina [cited 2012 Apr 20]. Available from: http://www.ibge.gov.br/home/estatistica/populacao/censo2010/tabelas_pdf/ total_populacao_santa_catarina.pdf

15. Prefeitura Municipal de Florianópolis. Secretaria Municipal de Saúde [homepage on the Internet]. Centros de saúde por distritos sanitários, áreas, modelo de atenção, número de micro-áreas e população [cited 2012 Apr 18]. Available from: http://esfflop.blogspot.com.br/2011/01/centros-de-saude-por-distritos.html

16. Prefeitura Municipal de Florianópolis. Secretaria Municipal de Saúde. Departamento de Informática [homepage on the Internet]. Sistemas de Informação [cited $2011 \mathrm{Jul}$ 10]. Available from: http://www.pmf.sc.gov.br/ entidades/saude/index.php?cms $=$ sistemas+de+informacao\&menu $=0$

17. Prefeitura Municipal de Florianópolis . Secretaria Municipal de Saúde [homepage on the Internet]. População de Florianópolis - 2010 [cited 2012 Apr 22]. Available from: http://www.pmf.sc.gov.br/sistemas/saude/unidades_saude/ populacao/uls_2010_index.php

18. Canadian Paediatric Society. Nutrition Committee. Meeting the iron needs of infants and young children: an update. Can Med Assoc J 1991;144:1451-4.

19. World Health Organization. Complementary feeding of young children in developing countries: a review of current scientific knowledge. Geneva: WHO; 1998.

20. Google Maps [homepage on the Internet]. Serviço de pesquisa e visualização de endereços, mapas e imagens [cited 2012 Mar 15]. Available from: http:// maps.google.com.br/
21. Correios [homepage on the Internet]. Busca CEP [cited 2012 Mar 16]. Available from: http://www.buscacep.correios.com.br/

22. Brasil - Conselho Nacional de Saúde. Resolução n 196, de 10 de maio de 1996. Aprova as diretrizes e normas regulamentadoras de pesquisas envolvendo seres humanos. Brasília: Diário Oficial da União; 1996.

23. Prefeitura Municipal de Florianópolis. Secretaria Municipal de Saúde [homepage on the Internet]. Vigilância alimentar e nutricional [cited $2012 \mathrm{Apr}$ 28]. Available from: http://portal.pmf.sc.gov.br/entidades/saude/index.php?c $\mathrm{ms}=\mathrm{vigilancia}+$ alimentar+e+nutricional

24. Brasil - Ministério da Saúde - PNAN [homepage on the Internet]. Programa Nacional de Suplementação de Ferro: quantitativo da população assistida [cited 2012 Apr 29]. Available from: http://nutricao.saude.gov.br/ferro_relatorio. php?ferro_tipo_relatorio $=3$

25. Vieira RC, Ferreira HS. Prevalence of anemia in Brazilian children in different epidemiological scenarios. Rev Nutr 2010;23:433-44.

26. Schultink W, van der Ree M, Matulessi P, Gross R. Low compliance with an iron-supplementation program: a study among pregnant women in Jakarta, Indonesia. Am J Clin Nutr 1993;57:135-9.

27. Batista Filho M, Ferreira LO. Prevention and treatment of irondeficiency anemia: new focuses and perspectives. Cad Saude Publica 1996;12:411-15.

28. De-Regil LM, Suchdev PS, Vist GE, Walleser S, Peña-Rosas JP. Home fortification of foods with multiple micronutrient powders for health and nutrition in children under two years of age. Cochrane Database Syst Rev 2011;(9):CD008959

29. Brasil - Ministério da Saúde - Política Nacional de Alimentação e Nutrição [homepage on the Internet]. Workshop de fortificação caseira no Brasil [cited 2012 May 01]. Available from: http://nutricao.saude.gov.br/workshop_ fortificacao.php 